\title{
Signal Transducer and Activator of Transcription Family Gene
}

National Cancer Institute

\section{Source}

National Cancer Institute. Signal Transducer and Activator of Transcription Family Gene. NCI Thesaurus. Code C25991.

Signal T ransducer and Activator of T ranscription Family Genes encode dual function cytoplasmic Signal T ransducer and Activator of Transcription (STAT) proteins that are activated by tyrosine phosphorylation in response to a large number of cytokines, growth factors, and hormones. After activation they form homodimers or heterodimers that translocate to the nucleus where they either bind directly to regulatory DNA cis-elements of specific target genes or act together with other DNA-binding proteins in multiprotein transcription complexes to direct transcription. $(\mathrm{NCl})$ 